\title{
A DARCIAN MODEL FOR THE FLOW OF BIG SPRING AND THE HYDRAULIC HEAD IN THE OZARK AQUIFER, MISSOURI, USA
}

\author{
DARCYJEV MODEL TOKA NA IZVIRU BIG SPRING IN \\ HIDRAVLIČNE VIŠINE V VODONOSNIKU OZARK, \\ MISSOURI, ZDA
}

\author{
Robert E. CRISS ${ }^{1}$
}

\begin{abstract}
UDC 556.33(737.8)

Robert E. Criss: A Darcian Model for the Flow of Big Spring and the hydraulic head in the Ozark aquifer, Missouri, USA

The complex discharge hydrograph for Big Spring, Missouri, can be described as the sum of two terms governed by Darcy's Law. The dominant, long-term component is proportional to the regional hydraulic gradient, and constitutes about $80 \%$ of the average flow of $12.6 \mathrm{~m}^{3} / \mathrm{s}$. Superimposed on this is a transient component with a time-constant of about 1.5 days that represents the Darcian response to sharp, rainfall-driven pulses on the head of the shallow groundwater system. This transient component delivers about $20 \%$ of the average total flow, but over short intervals can exceed the long-term component. However, the long-term component is so large that the ratio of record high flows to the average flow is only about $4 \mathrm{x}$ for Big Spring, and 1.5 to $4.5 \mathrm{x}$ for most other large Ozark springs; for comparison, this ratio is 10 to $3000 \mathrm{x}$ for most surface streams in Missouri. The strong correlation between the discharge of the large springs and the head in the Ozark aquifer permits the extension of the Darcian rainfall-runoff model to predict groundwater levels in wells.
\end{abstract}

Keywords: karst, springs, hydrograph, hydrologic modeling, Missouri.
Izvleček

UDK 556.33(737.8)

Robert E. Criss: Darcyjev model toka na izviru Big Spring in hidravlične višine v vodonosniku Ozark, Missouri, ZDA

Hidrogram izvira Big Spring (Veliki izvir) v zvezni državi Missouri (ZDA) lahko opišemo kot vsoto dveh členov izhajajočih iz Darcyjevega zakona. Prevladujoči počasni sestavni del je sorazmeren regionalnemu hidravličnemu gradientu in predstavlja približno $80 \%$ povprečnega iztoka, ki znaša $12,6 \mathrm{~m}^{2}$. $\mathrm{Na}$ to je naložen prehodni (hitri) sestavni deli, s časovno konstanto 1,5 dneva, ki predstavlja Darcyjev odziv na skok hidravlične višine, ki ga v plitvem delu vodonosnika povzročajo deževni sunki. Hitra komponenta predstavlja približno 20\% povprečnega skupnega iztoka, vendar lahko $\mathrm{v}$ krajših časovnih obdobjih preseže počasno komponento. Vseeno je slednja dovolj velika, da je razmerje med velikimi in povprečnimi pretoki izvira Big Spring le štiri, medtem ko je to razmerje 1,5 do 4,5 za večino drugih izvirov $\mathrm{v}$ Ozarkih. Za primerjavo, večina površinskih tokov v Missouriju ima razmerje med maksimalnim in povprečnim pretokom med 10 in 3000 . Močna korelacija med pretoki velikih izvirov in hidravlično višino v vodonosniku Ozark, omogoča uporabo Darcyjevskega modela napajanja in praznenja pri napovedi višine podzemne vode $\mathrm{v}$ vrtinah.

Ključne besede: kras, izviri, hidrogram, hidrološko modeliranje, Missouri.

\section{INTRODUCTION}

The ready availability of detailed, on-line, meterological and hydrological databases provides an important opportunity to advance the understanding of hydrologic systems and to improve and test hydrogeologic models. At the same time, the huge volume of available data can overwhelm a researcher unless simplifying, fundamen- tal principles are used to generate models of these complex natural systems. This paper uses Darcy's law and a theoretical rainfall-runoff model to interrelate detailed records of spring discharge, rainfall and well levels in a $10,000 \mathrm{~km}^{2}$ area in southern Missouri. In particular, the theoretical model of Criss and Winston (2008a, b) has

\footnotetext{
${ }^{1}$ Department of Earth \& Planetary Sciences, Washington University in Saint Louis, Missouri USA 63130, e-mail: criss@wustl.edu Received/Prejeto: 28.10.2009
} 
been used to successfully predict the hydrographs of many small rivers and springs using a single free parameter. However, experience shows that such simulations are much less accurate for features whose hydrographs have large baseflow components. This paper redresses this defect by superimposing the model predictions on a term describing the regional flow of groundwater, deduced from well observations. The latter approach provides an improved simulation of the discharge of the largest springs in the Ozarks, which have heretofore eluded predictive understanding. In a new application, the theoretical hydrograph model is extended to predict water levels in the Ozark aquifer from the detailed, long-term rainfall record.

\section{GEOLOGIC SETTING}

The Ozarks have ten "first magnitude" springs, defined as those whose average discharge exceeds $2.8 \mathrm{~m}^{3} / \mathrm{s}$, or $100 \mathrm{ft}^{3} / \mathrm{s}$. The largest of these, Big Spring, has an average flow of about $12.6 \mathrm{~m}^{3} / \mathrm{s}$, making it one of the largest single orifice springs in the world (Fig. 1; Vineyard \& Feder 1982). As discussed below, the catchment area required to supply Big Spring must be nearly $1,300 \mathrm{~km}^{2}$, because

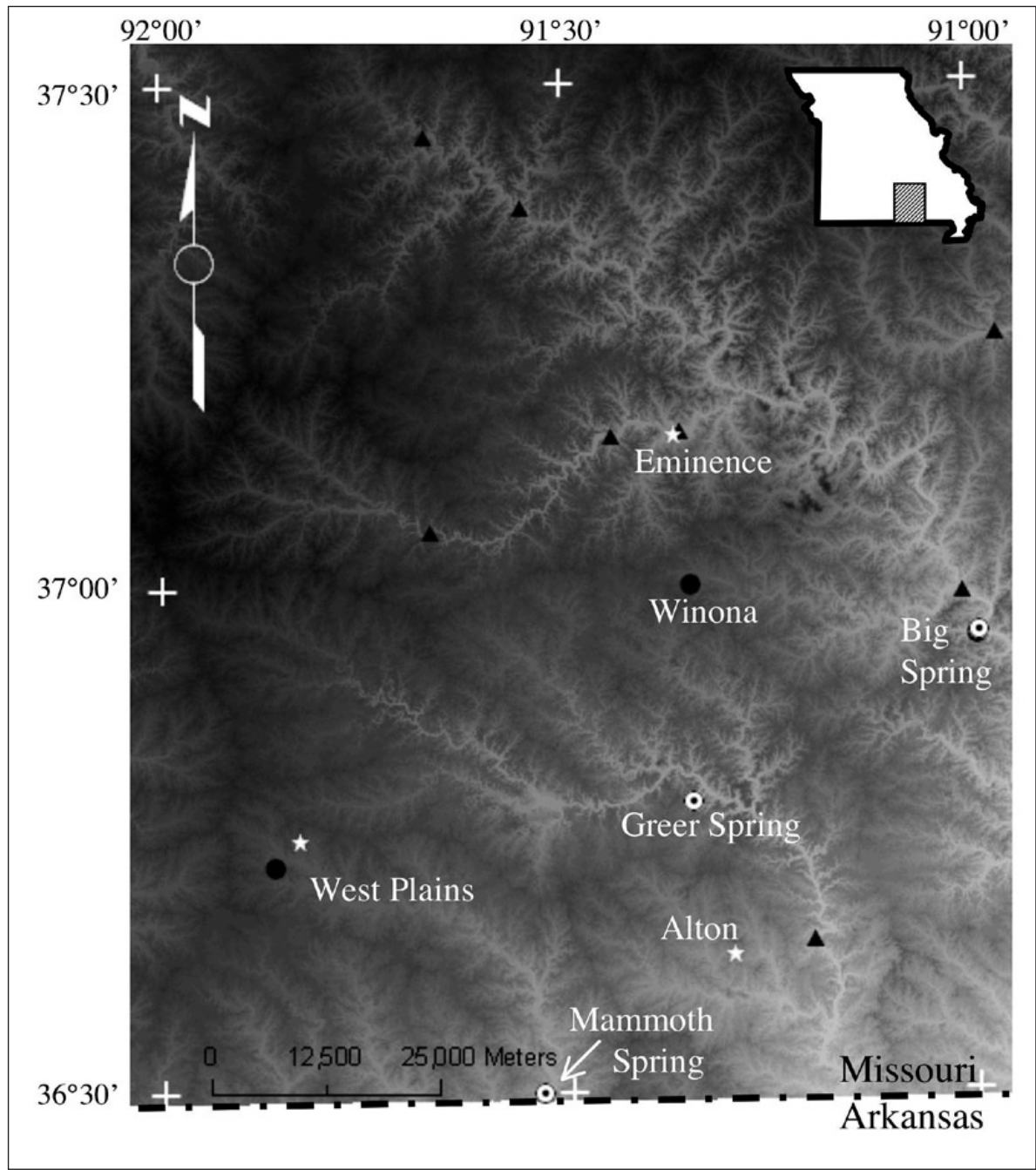

average runoff in this region is about $0.01 \mathrm{~m}^{3} / \mathrm{s}$ per $\mathrm{km}^{2}$ of basin area. Dye tracing studies by T.J. Aley and other workers, summarized in maps of Vineyard and Feder (1982) and Imes et al. (2007), establish subsurface water transport over lateral distances of at least $60 \mathrm{~km}$ in the Big Spring system, and show that the recharge area lies predominantly to the west of the spring orifice.

Big Spring emerges from an outcrop in the Eminence dolostone, a Cambrian formation that is part of a thick hydrostratigraphic unit called the Ozark aquifer (Imes 1988). The Eminence dolostone directly overlies the highly permeable Potosi formation, also Cambrian, that is characterized by large, drusy, interconnected vugs that make this formation a prolific aquifer (Homyk et al. 1967). The immediately underlying Derby-Doe Run and Davis formations are consid-

Fig. 1: Shaded digital elevation model of south-central Missouri (after MSDIS 2009) showing locations of features discussed in text including all sites listed in Tabs. 1 and 2. Symbols are as follows: large springs (open circles with dot); monitoring wells (solid dots); NOAA weather stations (white stars); USGS gaging stations (solid triangles). Inset map of Missouri shows area of detail. Elevations vary from about 100 $m$ above sea level in the southeast to nearly $500 \mathrm{~m}$ in the west. 
ered to be aquitards that effectively separate the Ozark aquifer from the lower, St. Francois aquifer system, constituted of Cambrian sandstone and dolostone units that directly overlie Precambrian basement. Other large springs discussed in this paper likewise derive their discharge from the Ozark aquifer, and most emanate from the Eminence formation or from predominantly dolostone units that overlie it (Vineyard \& Feder 1982).

\section{METHODS AND DATA}

A dimensionless theoretical hydrograph based on Darcy's law describes groundwater discharge following sharp precipitation events (Criss \& Winston 2008a, b):

$$
\frac{Q}{Q_{p}}=\left(\frac{2 e b}{3 t}\right)^{3 / 2} e^{-b / t}
$$

where $\mathrm{Q}$ is the flow at any time, $\mathrm{Qp}$ is the peak flow, $t$ is the time elapsed since the rainfall perturbation, $e$ is Euler's number, and the constant $\mathrm{b}$ is the characteristic response time of the watershed. The dimensionless ratio $\mathrm{Q} / \mathrm{Qp}$ varies from 0 to 1 , with peak flow being attained when the time is $2 \mathrm{~b} / 3$. This function embodies the mathematical characteristics of natural hydrographs, and accurately simulates the shape of hydrographs for many springs, creeks and small rivers in the Ozarks and elsewhere (Criss \& Winston 2008a, b). Criss and Winston (2008b; hereafter, CW 2008) extended this function into a rainfall-runoff model that incorporates evapotranspiration effects.

In what follows, the discharge variations of large Ozark springs are simulated by superimposing individually-scaled terms of equation 1, each representing "shortterm" perturbations driven by observed rainfall events, upon separately computed "long-term" flow variations. In particular, the CW (2008) computational model was used to simulate the short-term flow variations in the large Ozark springs. This model was found to be less effective for the computation of the long-term flow variations, so the latter were instead directly estimated from Darcy's law, which may be simplified for flow in one-dimension as:

$\mathrm{Q}=-\mathrm{KA} \Delta \mathrm{h} / \Delta \mathrm{x}$

where $\mathrm{K}$ is the hydraulic conductivity, $\mathrm{A}$ is the effective area, and $\Delta \mathrm{h}$ is the difference between water levels in two observation wells located $\Delta \mathrm{x}$ apart. In practice, a simple constant incorporating $\mathrm{K}$ and other factors was used to scale $\mathrm{Q}$ to the measured head difference between the observation wells. The overall model for the flow of Big Spring represents the sum of these "short-term" and "long-term" flow calculations. This approach differs from usual conceptual models of karst hydrologic systems that variously consider soil and epikarst storage, the structure of the conduit network, and similar details.

The detailed hydrological and meteorological records used in this paper are taken from USGS (2009a, b) and NOAA (2009) data archives. All are daily values, and all sites are in Missouri except for Mammoth Spring, which is in northernmost Arkansas, only $200 \mathrm{~m}$ south of the Missouri border (Fig. 1). All records are complete or nearly complete, but short missing intervals in groundwater head records were estimated by linear interpolation between the closest available daily values.

Tab. 1: Sources and Availability of Data.

\begin{tabular}{|l|l|l|l|l|}
\hline Site & Data type & Site number & Interval* & Reference \\
\hline Big Spring & discharge & 07067500 & $1921-2009 \#$ & USGS 2009a \\
\hline Greer Spring & discharge & 07071000 & $1921-2009$ & USGS 2009a \\
\hline Mammoth Spring & discharge & 07069190 & $1981-2009$ & USGS 2009a \\
\hline Winona Well & Water elevation & 370003091205301 & $2008-2009$ & USGS 2009b \\
\hline Big Spring Well & Water elevation & 365654091001301 & $2004-2009$ & USGS 2009b \\
\hline West Plains Well & Water elevation & 364324091515001 & $2000-2009$ & USGS 2009b \\
\hline Eminence 1N & precipitation & 232619 & $1991-2009$ & NOAA 2009 \\
\hline Alton 6SE & precipitation & 230127 & $1994-2009$ & NOAA 2009 \\
\hline West Plains & precipitation & 238880 & $1948-2009$ & NOAA 2009 \\
\hline
\end{tabular}

${ }^{\star}$ Period of nearly continuous daily data; \# 1996-1999 data are unavailable for Big Spring 


\section{MEAN, MAXIMUM AND MINIMUM FLOWS}

Systematic variations of the mean, minimum and maximum flows of Missouri watersheds provide insight into the Big Spring system. A strong linear correlation exists between mean annual discharge and basin area for surface catchments, such that, on average, $1 \mathrm{~m}^{3} / \mathrm{s}$ of flow is provided by approximately $100 \mathrm{~km}^{2}$ of basin area in southern Missouri (Fig. 2). For an individual site, the actual average flow may vary from this estimate, depending on the average rainfall in the catchment, which is geographically variable, and depending on whether a particular stream reach gains or contributes water to the regional groundwater system. Nevertheless, the overall relationship for southern Missouri provides a useful guide. Using the regression line in Fig. 2 as a basis, the mean discharge of Big Spring of $12.6 \mathrm{~m}^{3} / \mathrm{s}$ suggests that the effective catchment area is about $1280 \mathrm{~km}^{2}$, probably larger that the estimate of about $1100 \mathrm{~km}^{2}$ made by Imes et al. (2007).

More interesting is the total range of discharge variations at a particular site. The record maximum discharge of Big Spring is only about 3 to 4.5 times larger than the mean annual discharge. Peak flows are difficult to measure, and the difficulties at Big Spring are exacerbated by backflooding of the spring orifice by the Current River during periods of high flow. Consequently, estimates for the record maximum flow of Big Spring have large uncertainty and vary from 34 to $57 \mathrm{~m}^{3} / \mathrm{s}$ ( $c f$. Imes et al. 2007; USGS 2009a). Nevertheless, when compared to surface catchments having comparable mean flow, the peak flows of large Missouri springs are 30 to $100 \mathrm{x}$ smaller (Tab. 2). For example, at the Eminence gauging station, the Jacks Fork tributary of the Current River has a basin area of $1030 \mathrm{~km}^{2}$ and a mean flow of 13.1 $\mathrm{m}^{3} / \mathrm{s}$, comparable to the mean discharge of Big Spring. However, the record flow $\left(1660 \mathrm{~m}^{3} / \mathrm{s}\right)$ of the Jacks Fork at this site dwarfs either estimate for the record flow of Big
Spring. This large difference between these maximum flows exemplifies the huge, long-term, baseflow contributions to Ozark springs.

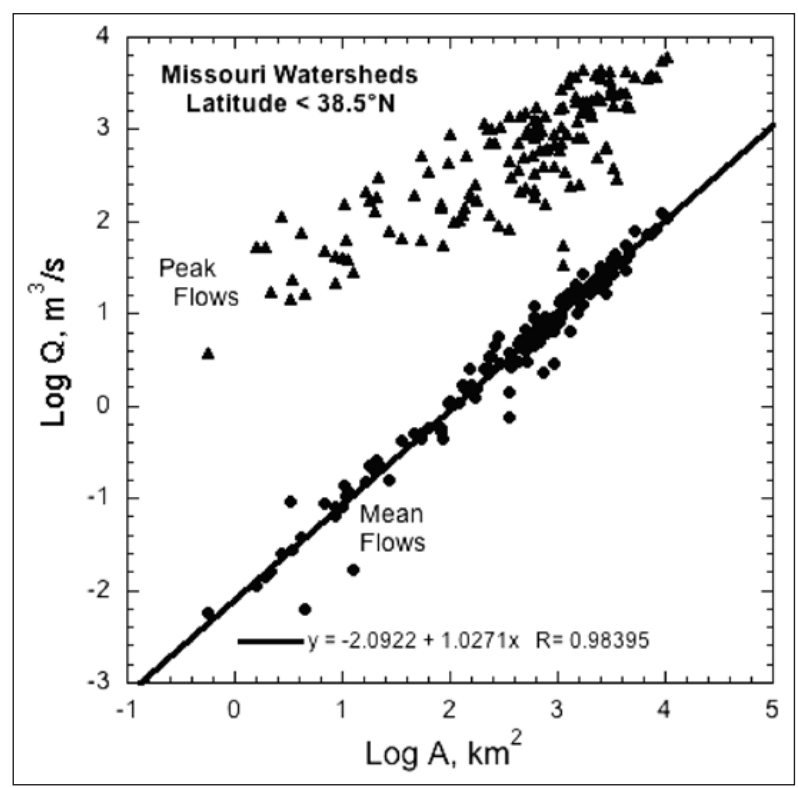

Fig. 2: Graph of mean flows and record high flows versus basin area, for all gaging stations on surface streams within southern Missouri, south of latitude 38 30'. Mean flows are strongly correlated with basin area and have close to a unit slope on this loglog plot, with mean discharge being about $0.01 \mathrm{~m}^{3} / \mathrm{s}-\mathrm{km}^{2}$. Peak flows for surface streams are typically 10 to $3000 x$ greater than mean flows, and their trend line has a lower slope.

Similarly, the record minimum flow for Big Spring is $53 \%$ of the mean flow, and at least $12 \%$ of the record maximum flow, so the total range of variation is only about eight-fold. Similarly small variations in discharge are seen for Greer Spring and Mammoth Spring (Tab. 2), and for numerous other large Ozark Springs (Vineyard

Tab. 2: Mean, maximum and minimum flows for large springs and proximal surface streams.

\begin{tabular}{|l|l|l|l|l|l|l|}
\hline Site & $\begin{array}{l}\text { Basin Area, } \\
\mathrm{km}^{2}\end{array}$ & Site number & $\begin{array}{l}\text { Mean Flow, } \\
\mathrm{m}^{3} / \mathrm{s}\end{array}$ & $\begin{array}{l}\text { Maximum } \\
\text { Flow, } \mathrm{m}^{3} / \mathrm{s}\end{array}$ & $\begin{array}{l}\text { Minimum } \\
\text { Flow, } \mathrm{m}^{3} / \mathrm{s}\end{array}$ & $\begin{array}{l}\text { Max: Min } \\
\text { Ratio }\end{array}$ \\
\hline Big Spring & $1280^{*}$ & 07067500 & 12.6 & 56.6 & 6.7 & 8.5 \\
\hline Greer Spring & $990^{*}$ & 07071000 & 9.7 & 50.1 & 2.9 & 17.0 \\
\hline Mammoth Spring & $1010^{*}$ & 07069190 & 9.9 & 20.0 & 4.9 & 4.1 \\
\hline Jacks Fork nr Mountain View & 480 & 07065200 & 5.5 & 1230. & 0.4 & 2910 \\
\hline Jacks Fork at Alley Spring & 770 & 07065495 & 7.3 & 1380 & 0.6 & 2210. \\
\hline Jacks Fork at Eminence & 1030 & 07066000 & 13.1 & 1660 & 1.8 & 910. \\
\hline Current R. at Van Buren & 4320 & 07067000 & 56.0 & 3540 & 13.4 & 264 \\
\hline North Fork R. & 1450 & 07057500 & 20.9 & 3770 & 5.3 & 710 \\
\hline
\end{tabular}

*Estimated from Fig. 2.

Data source: USGS (2005a, b). 
\& Feder 1982). In contrast, the minimum flow at the Jacks Fork at Eminence is only about $14 \%$ of the mean flow, and nearly a thousand times less than the record maximum flow (Tab. 2).

In short, the "baseflow" contributions to Big Spring and other large Ozark springs are very significant, so the total range of flow variation in these springs is much smaller than that in surface streams having comparable mean flows. These large "baseflow" contributions complicate their simulation by the CW (2008) model, and are responsible for the subdued variations in the physical, chemical and isotopic character of the springs.

\section{EMPIRICAL HYDROLOGIC CORRELATIONS}

Insight into the nature of Ozark hydrology is afforded by simple intercomparison of detailed data sets. Variations in discharge among various sites are strongly correlated, particularly if surface streams are compared to other surface streams, and large springs are compared to other large springs. As an example, the flow of Greer Spring closely parallels that of Mammoth Spring, according to the following linear regression to daily mean discharge $\left(\mathrm{m}^{3} / \mathrm{s}\right)$, available over the last 28 years:

Qgreer $=1.17^{\star}$ Qmammoth $-1.3 \mathrm{R}=0.895$

The correlations between the discharge of Big Spring and either the flow of Mammoth Spring, Greer Spring, or an arbitrary linear combination of those, are

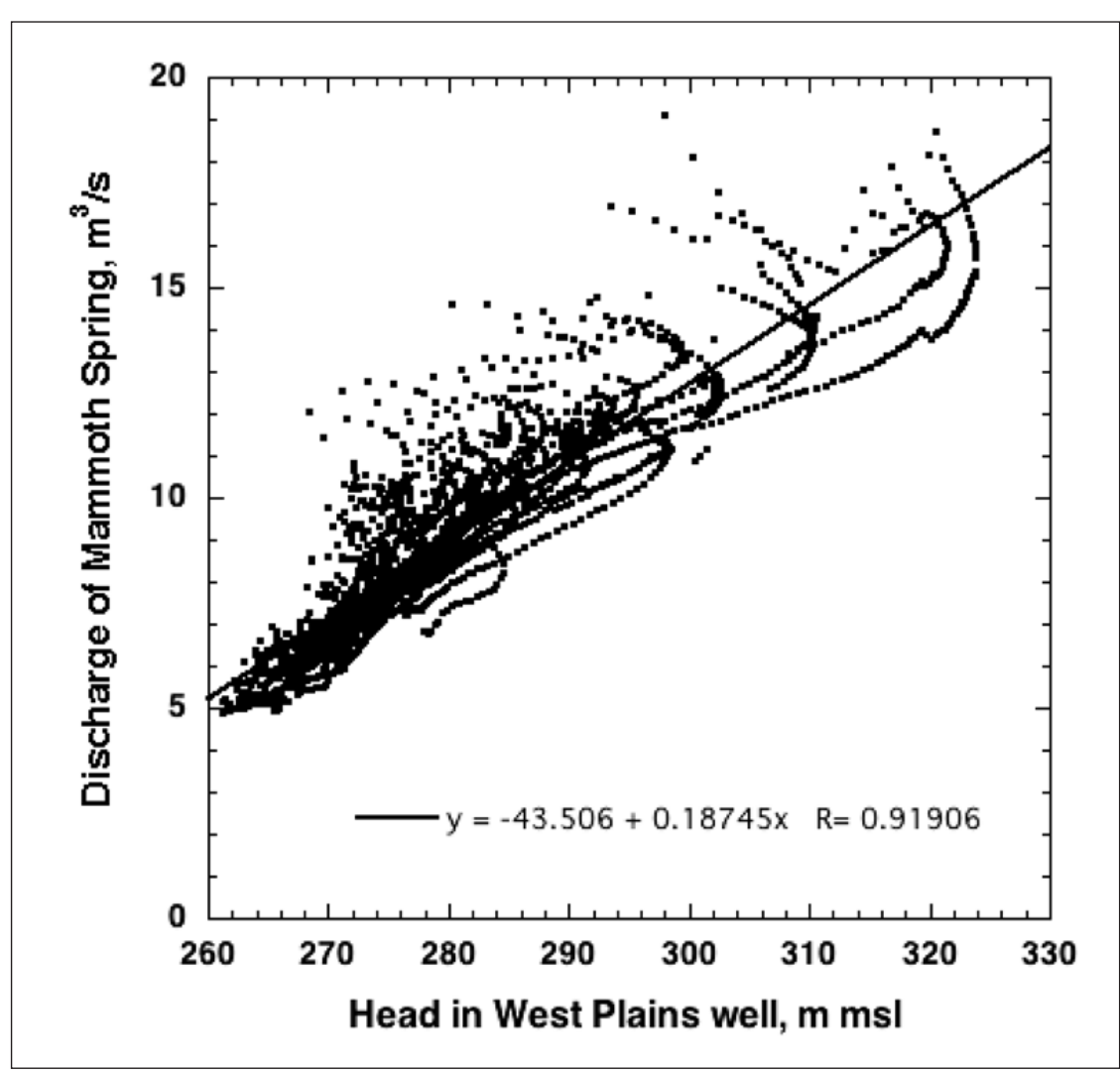

slightly weaker with $\mathrm{R}$ values being generally between 0.80 to 0.86 . Also interesting are correlations between spring discharge and water levels in the Ozark aquifer, measured in several non-pumping observation wells (Tab. 1). For example, James Vandike (written communication, 2009) noted a strong correlation between the flow at Mammoth Spring and the head, Hwp, in meters above sea level in the West Plains, Missouri observation well, found here to be (see Fig. 3):

Qmammoth $=0.187^{\star}$ Hwp $-43.5 \mathrm{R}=0.919$

Hydraulic head maps and dye traces show that groundwater transport is generally aligned from West Plains to Mammoth Spring (Imes et al. 2007), qualitatively explaining this correlation. In particular, the stage of the large pool at Mammoth Spring changes very little, varying only about $\pm 15 \mathrm{~cm}$ from the usual pool elevation of about $154 \mathrm{~m}$. Thus, eq. 4 is basically consistent with Darcy's law, with the caveat that over long distances, the hydraulic head gradient would be curvilinear (e.g., Worthington 2009). While equations 3 and 4 are only simple empiricisms, the data sets they represent are large, and the strong correlations suggest that the dominant, long-term flow component in large Ozark springs is governed by the head in the Ozark aquifer.

Fig. 3: Relationship between the observed daily discharge of Mammoth Spring and the head in the West Plains observation well, located $39 \mathrm{~km}$ to the northwest (see Fig. 1). This plot shows all available data (>2900 points) collected during 2000-2009. 


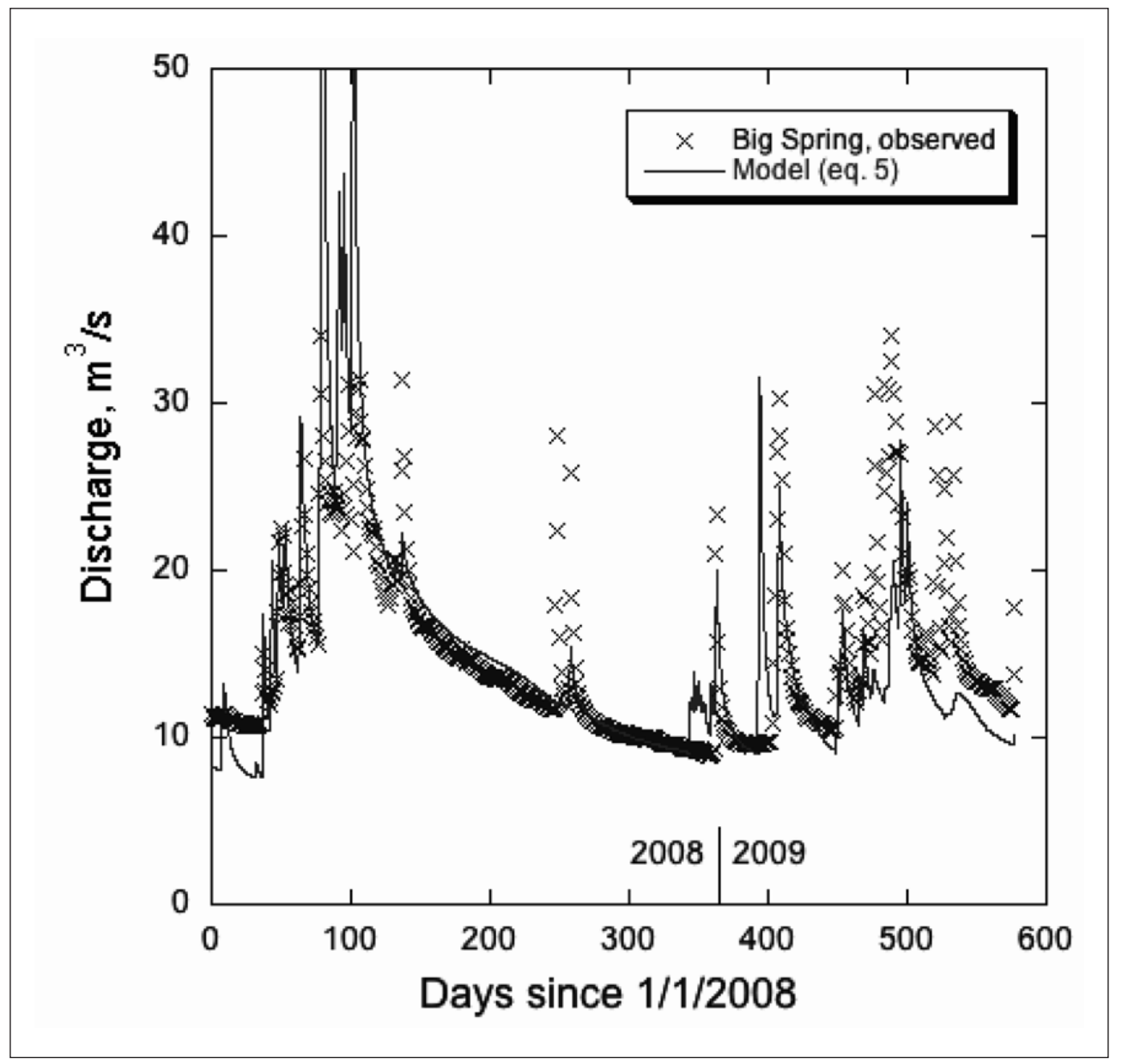

Fig. 4: Observed discharge of Big Spring (x's) vs. the predicted sum (eq. 5) of long-term and short-term flows (see text). The short-term flow was calculated by the CW (2008) model for a time constant of 1.5 days, driven by the mean daily rainfall observed at Eminence, West Plains and Alton (Tab. 1).

\section{DISCHARGE MODEL FOR BIG SPRING}

The above correlations suggest that the discharge variations of Big Spring and other large Ozark Springs might represent the superposition of "short-term" flows on a dominant, "long-term" component. The West Plains well, discussed above, is not optimal for a Big Spring model because this well is located far from the spring orifice and outside its probable recharge area. Instead, the long-term flow of Big Spring (Fig. 4) is modeled as being proportional, via Darcy's law, to the simple difference between the groundwater levels measured in observation wells at Winona in Shannon County and near the Big Spring orifice in Carter County, $34 \mathrm{~km}$ to the east (see Tab. 1). Unfortunately, daily records for the Winona well span less than two years.

Short-term flow variations in Big Spring were assumed to be driven by rainfall perturbations, taken as the average daily precipitation recorded by NOAA at Eminence, Alton and West Plains (Tab. 1), corrected for evapotranspiration losses. The results were computed by applying the CW (2008) model to this meteorological record. These calculated flow variations were superimposed on the model for long-term flow, just described. The effective time constant " $b$ " of 1.5 days that was used in this short-term model was chosen to reproduce the time-scale of the sharp spikes in the observed flow record for Big Spring. Finally, the relative importance of the long-term and short-term components was found to be roughly $80: 20$ by optimizing the strength of the regression line on a graph of predicted vs. measured flows, and the mean predicted flow was scaled to match the mean observed flow to remove bias (Fig. 4). The resultant "Model" equation is:

$$
\mathrm{Q}=0.17^{\star} \mathrm{CW}+0.2^{\star}\left(\mathrm{H}_{\mathrm{w}}-\mathrm{H}_{\mathrm{b}}\right)
$$


where $\mathrm{Q}$ is the simulated flow in $\mathrm{m}^{3} / \mathrm{s}$, CW is the output of the CW (2008) model for a $1280 \mathrm{~km}^{2}$ basin having a time constant of 1.5 days, and $\mathrm{Hw}$ and $\mathrm{Hb}$ respectively are the elevations of the water table in meters relative to sea level in the wells at Winona and near Big Springs. The numerical coefficients $(0.17$ dimensionless, and $0.2 \mathrm{~m}^{2} / \mathrm{s}$ ) were made as simple as possible to emphasize the inherent inaccuracy of this model, given the short modeling timeframe and the inadequacy of the composite precipitation record to represent the rainfall in the large recharge area. Note that this model also utilizes only a single lumped parameter for groundwater transport, and a rudimentary estimate of regional groundwater heads, so it is easy to calculate. On a graph of model flow (eq. 5) vs. the observed flow, the correlation coefficient for the linear regression is 0.68 .

Inspection of Fig. 4 shows that this model captures the general character of the observed flow variations of Big Spring. However, significant overestimates and underestimates of flow magnitude are common on short time scales. Note that the mismatch between actual and predicted short-term flow tends to be greatest during summer and fall, when rain events are often intense but geographically spotty, and evapotranspiration corrections are largest. More detailed meteorological records corrected by more complex evapotranspiration algorithms will be needed to rectify such defects.

\section{GROUNDWATER LEVEL VARIATIONS}

The correlations between spring discharge, groundwater levels, and precipitation, and their successful quantitative linkage by Darcy's law and the CW (2008) rainfall-runoff model, suggests that the latter model may provide a means to predict water levels in wells from rainfall records. The CW (2008) model is not ideally suited for this because it treats contributions to the head at the water table as delta functions, but there are ways to circumvent this problem. The easiest way is to use Darcy's law to back-calculate the elevation of the water table from the discharge predicted by the CW (2008) rainfall-runoff model, ignoring short term timing details and the curvilinear character of actual hydraulic gradients in large karst systems.

According to Darcy's law, the discharge per unit area, Q' measured at a point of low head, $h_{p}$, is proportional to the difference between that head and a point of higher head, $h_{u^{\prime}}$, here taken to be the elevation of the water table. Thus, eq. 2 may be rewritten as:

$\mathrm{h}_{\mathrm{u}}=\mathrm{h}_{\mathrm{l}}+\mathrm{c}^{\star} \mathrm{Q}^{\prime}$

where $c$ is a constant that includes the hydraulic conductivity. Straightforward linear regression can be used to optimize the correlation between predicted values for Q' and the water table elevation $\left(h_{u}\right)$ in an observation well, where Q' is determined from the CW (2008) model and the precipitation record for various choices of the time constant " $b$ " (see eq. 1).
Fig. 5 compares the daily values of the water levels in the West Plains observation well to the hypothetical discharge predicted by the CW (2008) model, determined for a hypothetical $1 \mathrm{~km}^{2}$ basin, driven by the rainfall recorded at West Plains, and assuming a time constant of 30 days. The indicated linear regression equation between the two curves is:

$h_{u}=259+1670 Q^{\prime} \quad R=0.907$

where $\mathrm{h}$ is in meters above sea level, and Q' is in $\mathrm{m}^{3} / \mathrm{s}-\mathrm{km}^{2}$.

The strong correlation coefficient of 0.9 suggests that useful prediction of future water levels at West Plains can be made from rainfall measured nearby. Predicted well levels should also be reasonably accurate for the interval between 1948 and 2000, when rainfall records but not well observations were available at West Plains. It is possible that the site chosen for this modeling effort was a fortunate one, in that the well may lie near a groundwater divide, so that the inflow to the aquifer could be considered as rainfall additions on overlying ground, uncomplicated by groundwater inflow from elsewhere. 


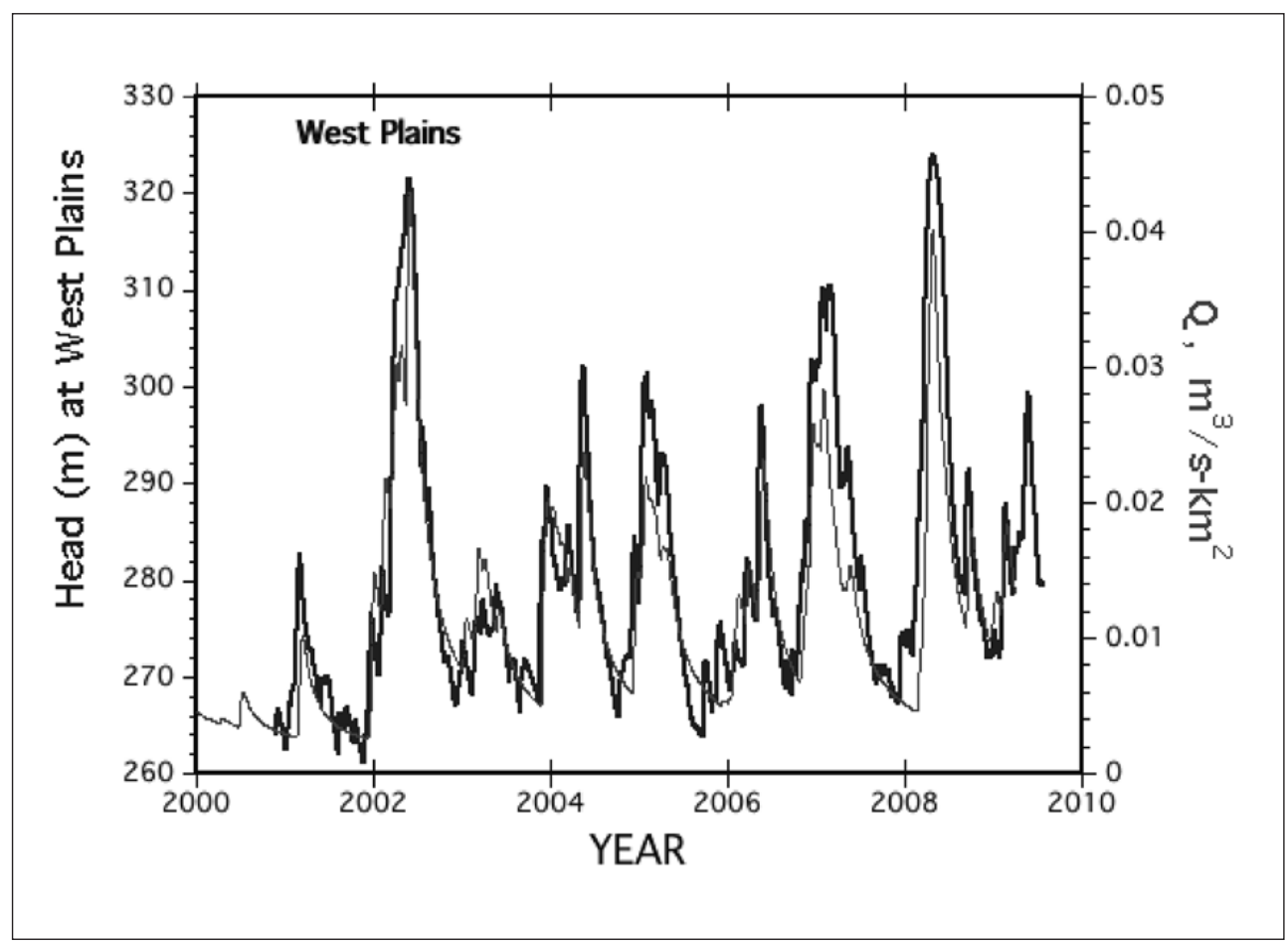

Fig. 5: Daily groundwater levels in the West Plains observation well (thick line, left scale) in meters relative to sea level, compared to hypothetical discharge per square kilometer from an aquifer calculated for a CW (2008) model with a time constant of 30 days thin line, right scale).

\section{CONCLUSIONS}

Ozark springs are dominated by a "long-term" flow component that is proportional to the head in the Ozark aquifer. Superimposed on this comparatively steady flow are sharp, short-term perturbations that are driven by recent rainfall. Darcy's law and a derivative, rainfall-runoff model can explain and predict these flow variations in the large springs. An unexpected outcome was the successful modeling of the head in a well in the Ozark aquifer by the rainfall-runoff model.

\section{REFERENCES}

Criss, R. \& W. Winston, 2008a: Properties of a diffusive hydrograph and the interpretation of its single parameter-- Mathematical Geoscience, 40, 313-325 (doi:10.1007/s11004-008-9145-9).

Criss, R. \& W. Winston, 2008b: Discharge predictions of a rainfall-driven theoretical hydrograph compared to common models and observed data.- Water $\mathrm{R}$ sources Research, 44, W10407, 9 p. (doi:10.1029/ 2007WR006415).

Homyk, A., Harvey, E. \& H. Jeffreys, 1967: Water Resources.- Mineral and Water Resources of Missouri, Report of the Missouri Division of Geological Survey and Water Resources and the United States Geological Survey, 43, 253-399.
Imes, J., 1988: Geohydrology and hydrochemistry of the Ozark plateaus aquifer system.- American Water Resources Association, AWRA Monograph Series, 13, 165-178.

Imes, J., Plummer, L., Kleeschulte, M. \& J. Schumacher, 2007: Recharge area, base-flow and quick-flow discharge rates and ages, and general water quality of Big Spring in Carter County, Missouri, 2000-04.- U.S. Geological Survey Scientific Investigations Report, 2007-5049, 1-80.

MSDIS, 2009: Missouri Spatial Data Information Service.- [Online] Available from: http://msdis.missouri.edu/ [Accessed October 2009]. 
NOAA, 2009: NNDC Climate Data Online.- [Online] Available from: http://cdo.ncdc.noaa.gov/cgi-bin/ cdo/cdostnsearch.pl [Accessed October 2009].

USGS, 2005a: Water Resources Data, Missouri, 2005, Water-Data Report MO-05-1, 724 p.- [Online] Available from: http://pubs.usgs.gov/wdr/ [Accessed August 2009].

USGS, 2005b: Water Resources Data, Arkansas, 2005, Water-Data Report AR-05-1, 438 p.- [Online] Available from: http://pubs.usgs.gov/wdr/ [Accessed August 2009].

USGS, 2009a: USGS Real Time Data for Missouri. Daily Streamflow.- [Online] Available from: http://waterdata.usgs.gov/mo/nwis/rt [Accessed October 2009].
USGS, 2009b: USGS Real Time Data for Missouri. Groundwater.- [Online] Available from: http://waterdata.usgs.gov $/ \mathrm{mo} / \mathrm{nwis} / \mathrm{current} /$ ?type $=\mathrm{gw} \quad[$ Accessed October 2009].

Vineyard, J. \& G. Feder 1982: Springs of Missouri.- Missouri Division of Geology and Land Survey, Water Resources Report, 29, 1-212.

Worthington, S., 2009: Diagnostic hydrogeologic characteristics of a karst aquifer (Kentucky, USA).- Hydrogeology Journal. DOI 10.1007/s10040-009-0489-0. 